\title{
Critical Reflections on UNISA's Decolonial Summer School: In Conversation with Rozena Maart
}

\section{Puleng Segalo \\ ORCID iD: https://orcid.org/0000-0001-7724-5434}

\section{Abstract}

The call to decolonise the university more broadly, and the curricula in particular, has sparked the need to interrogate what it means to decolonise. In this article I discuss the Decolonial Summer School held at the University of South Africa and offer existential reflections on my role as an educator within the team responsible for its organisation. The methodology employed in this article utilises a question-and-answer format to provide reflections on key questions that were posed to me by Rozena Maart in an attempt to engage me on the purpose, objectives, plans, and my pedagogical stance of the Decolonial Summer School. It is hoped that these reflections will offer insights into the reasons for hosting the Decolonial Summer School, the accomplishments, challenges encountered, and the possibilities for the future. At a time in the world where seeking answers to the question of what it means to be human has become more urgent than ever, a Decolonial Summer School offers the opportunity for those involved to be 'armed' and to sharpen their tools to respond to everyday challenges. The conversational approach in this article focuses on the overall aim of the Decolonial Summer School, which is to highlight its significance in forging ahead with decolonial thinking, not only in terms of thought production or curriculum adjustment and mindset, but rather in developing a language that one can use to challenge the very systems of thought, for example the very Eurocentric language and discourse, that one is against, and which leaves one outside of the process of knowledge production.

Keywords: Decolonial Summer School, decoloniality project, colonialism, coloniality, higher education, University of South Africa 


\section{Puleng Segalo}

\section{Introduction}

The call to decolonise the university more broadly, and the curricula in particular, has sparked the need to interrogate what it means to decolonise. In this article I discuss the Decolonial Summer School (hereafter referred to as the school, except in direct quotations) held at the University of South Africa (UNISA) and offer existential reflections on my role as an educator organising of the school. The methodology employed in this article utilises a questionand-answer format to provide reflections on key questions that were posed to me by Rozena Maart, a professor in the School of Social Sciences at the University of KwaZulu-Natal, in an attempt to engage me on the purpose, objectives, plans, and my pedagogical stance of the school. It is hoped that these reflections will offer insights into the reasons for hosting the school, the accomplishments, challenges encountered, and the possibilities for the future. At a time in the world where questions of what it means to be human have become more urgent than ever, the school offers the opportunity for those involved to be 'armed' and to sharpen their tools to respond to everyday challenges. The conversational approach in this article focuses on the overall aim of the school which is to highlight its significance in forging ahead with decolonial thinking, not only in terms of thought production or curriculum adjustment and mindset, but rather in developing a language that one can use to challenge the very systems of thought - for example the very Eurocentric language and discourse - that one is against, and which leaves one outside of the process of knowledge production.

\section{Creating the Platform by which to Carry out a Decolonial Summer School}

ROZENA MAART: How did the Decolonial Summer School fit into your portfolio, in terms of your academic experience and expertise, your own work, as well as your position within management as the Head of Research and Graduate Studies?

PULENG SEGALO: The Decolonial Summer School was a project that was started by the College of Human Sciences, at UNISA, in 2014. The project came about as a result of a number of scholars coming together to engage on the ways that academia continues to perpetuate the colonial project through which teaching happens, and how it happens. These were questions that we 
needed to address. The decolonial project aims to serve as a platform that offers a space for speaking back to, questioning, challenging and critiquing what we inherited under apartheid and colonialism, and as such is an attempt to interrupt the status quo. The space that was created initially started as a reading group, followed by a select number of academics from UNISA who attended the Decolonial Summer School in Barcelona in 2012. This particular Summer School idea was brought to South Africa, with the hope of it serving as a platform that offers the chance to engage with what it means to decolonise, to ask the crucial question: 'What is decolonisation?' Housed in the College of Human Sciences, the project was assigned to the Office of Research and Graduate Studies, and as the then head of the Office (2016 - 2019), I coordinated and oversaw the successful running of the project. I immediately immersed myself in the work and the task at hand. It became easy to lead the project, as I believed in it and because it spoke to my own work, the questions I had been grappling with in my own discipline and the challenges I have with the whole notion of 'the University' as it currently stands. The Office of Research and Graduate Studies is mandated to offer support to all researchrelated and postgraduate activities. The Office is further tasked with ensuring a smooth journey for all registered postgraduate students in the Human Sciences. As a result of the mandate of the Office, the hosting of the decoloniality project was a great fit, as it is in line with the importance of conducting research and producing knowledge, while also focusing on postgraduate studies as a stage that affords the opportunity for thinking differently and critically. Thinking from a decolonial perspective is in line with the College's transformation agenda. It is also pertinent to highlight that the School is not limited to the Human Sciences as we have participants from other disciplines such as Law, Education, Economics, and the Natural Sciences more broadly.

\section{The Conceptual Understanding of Decolonial and Decoloniality}

ROZENA MAART: What kind of conceptual understanding of 'decolonial' and 'decoloniality' did you enter the project with?

PULENG SEGALO: My work is at the intersection of Psychology, and Gender Studies with a specific focus on gender and trauma. My research interest is also in African Psychology, where I focus on what it means to engage 


\section{Puleng Segalo}

the discipline from an African perspective. The following scholars offered me the theoretical tools to approach African Psychology: Frantz Fanon (1986), Paulo Freire (2007), Chabani Manganyi (2013), Augustine Nwoye (2015; 2017), and Kopano Ratele (2016). The following authors equipped me with a lens to approach decoloniality: Ngugi wa Thiong'o (1986), Ramon Grosfoguel (2007), Nelson Maldonado-Torres (2011), Sabelo Ndlovu (2013), and Walter Mignolo (2013) among others; and Oyeronke Oyewumi (1997) and Maria Lugones (2010) assisted with engaging feminism through a decolonial and Africanist lens. I became part of the decoloniality project with [a] minimal understanding of the various ways in which decoloniality had been defined, understood and used to challenge the notion of colonialism and coloniality. Attending the first Decolonial Summer School in Europe, in Spain actually, exposed me to various decolonial scholars who mainly came from South America, although based in North America, and it is through their framing of the key concepts that I started grappling with possible ways to apply what I had grasped in my own context, South Africa.

\section{The Direction of the UNISA Decolonial Summer School, Language and Cultural Identity \\ ROZENA MAART: Why a School?}

PULENG SEGALO: Since its independence in 1994, South Africa has been on a journey to redefine itself and tackle everyday challenges that perpetually confront it. This redefining required reflections from all sectors of society. Coming from a history where black people were subjected to an inferior system of education called 'Bantu Education', it became pertinent to zoom in on the education sector. Education remains one of the pillars of society that provides tools to engage social injustices and inequalities that affect how communities function. Many people continue to suffer from the historical traumas of colonialism and apartheid and as a result there remains a need to find a vocabulary that can assist with articulating the impact of this past and the possible future that could be envisaged. To this end, a School on decoloniality was critical as it was hoped that it could provide a platform for the needed reimagination, reflection, remembering, and rethinking of where we come from and the implications thereof for the present. In his 2009 book $R e$ membering Africa, wa Thiong'o reminds us that we cannot put the pieces 
together of who we once were if we do not reclaim our languages, our rituals, poems, and cultural symbols. We need to re-learn what these meant to us as Africans before the colonial interruption.

As indicated earlier, hosting the Decolonial Summer School at UNISA, in South Africa, is aimed at allowing a cohort of emerging and established scholars an opportunity to engage with what it means to decolonise. The School aims at affording participants the opportunity to learn, question, critique, learn, un-learn and, hopefully, re-learn. Over the seven years that the school has been in existence, it moved from being one week-long, then two weeks [in length] and, in 2019, it went back to one week. The duration of the school has been determined by the feedback received from participants. The intensive engagements are meant to bring together a diverse group of people, who are at different levels of their academic journeys and careers; to learn from each other, to un-learn some of the toxic 'untruths' that the Euro-Western education system has offered them, as truth and fact. Overall, the School aims at providing the space to breathe outside of the limitations of an academy that still chokes us with European scholarship as many people walk around with immense suffocation.

\section{Education and Training and the Move towards Criticality: Producing Critical Thinkers}

ROZENA MAART: Is the focus on education and training or is it broader than that? Is it also about a community of scholars, from across the country, collaborating on a platform in order to establish, develop and produce knowledge?

PULENG SEGALO: The focus of the Summer School, specifically, and the decolonial project, more broadly, is on training and education, but also to produce critical thinkers, who are able to critique their respective disciplines and start rethinking some of the ways they have been taught, and how they, themselves, teach and understand knowledge production. The aim is further to produce a cohort of scholars, not only nationally across institutions but also internationally, with a focus on geographical locations that have suffered colonialism and its remnants through coloniality. The interdisciplinary nature of the school allows the participants to cross-pollinate, see common challenges, collectively think of alternative ways to approach teaching and learning, and 


\section{Puleng Segalo}

to refute the notion of universality. The School allows for a community of scholars from across the country to contribute to the production and development of knowledge, and to collaborate with scholars through publishing together. To this end, the school has a specific focus and anticipated outcomes which I outline below, in random order:

1. Modernity, Eurocentrism and coloniality: Whilst theoretical shifts in modernity have addressed notions of Eurocentrism and coloniality, the importance of the Summer School where invited presenters grapple with this particular trajectory and share their knowledge with scholars in attendance within the context of South Africa, was an important way to see how this would play out. One of the issues highlighted at the Summer School is the importance of trans-modernity, which aims to create multiepistemic spaces, and the need to acknowledge multiple ways of knowing and being in the world. Trans-modernity is a notion of epistemic diversity which allows for inter-epistemic dialogue.

2. Epistemic racism/patriarchy/sexism: In the past few years, South Africa has experienced an increase in individual encounters of racism. One either has to page through newspaper articles or watch the news to see just how prevalent reports of racism have been in the country. The fight against racism has been a long overdue struggle, that did not just disappear because of [changes to] formal legislation. It is therefore critical to engage in discussions to better understand the ways in which racism continues to show itself in the everyday experiences of people, in their interaction, in the workplace, within schools and in the streets. There are multiple markers of racism: for example, religion, ethnicity, and language, among others. The Decolonial Summer School aims at showing ways in which colonialists racialised their colonial subjects in many different ways, on many different levels, to achieve their goal of 'divide and rule'. A further highlight is how racialised groups that were given privileges by the colonialists continue to perpetuate injustices along religion, ethnicity, gender, and even class lines. To this end, we draw from feminist scholars such as Oyewumi (1997) who has shown in her work that patriarchy has not always been the norm in some parts of Africa. We also draw from scholars such as Angela Davis (1983) who problematises the category of gender and makes a claim that this category is not universal. Davis further argues that gender is the privilege 
of white women since black women were perceived as 'female', almost equated to the status of animals, for the longest time.

3. Zone of being/ zone of non-being: Drawing from scholars such as Fanon (1961) and Boaventura de Sousa Santos (2016), the school engages with what it means to be considered sub-human and the role which coloniality plays in creating these confined lines wherein humanity is defined. The school highlights the material effects of existence at various levels of humanity. Racism plays out violently within these zones of being, where one sees for example, the denial of recognition of an ethical code for those deemed to belong to the zone of non-being. The school further engages the ways in which the dialectic of I and 'Other' collapses in the zone of non-being.

4. Coloniality of being and subjectivity: The school engages with and shows the ways in which the modern world continues to be colonial in nature. We have coloniality at the level of being and knowledge. In modernity, our existence is described in ways that highlight how groups and communities of people are dominated and exploited, which are maintained through power. We further highlight the ways in which coloniality of being, knowledge, and power are equally fundamental and interrelated. The school further provides conceptual tools that attempt to assist us in understanding how coloniality operates. We look at the role of political activism, intellectual work, and artistic creation; we also engage with forms of activity that offer possibilities for concrete change toward decoloniality.

5. Africa and the modern world: Here we focus on the historical perspectives of resistance and nationalism and their legacies on the African continent. It is critical to note the erosion of history and to see the problematic nature in which history is represented. For example, the convention in Berlin where Africa was divided, does not form part of formal conversations or history texts, and this exclusion we see as intentional, so as to obscure the past. We draw from some of the architects of Africa's international relations such as W. E.B. du Bois whose work focused on showing how the problem of the 20th century is the problem of the colour line; secondly, we have C. L. R. James who insisted that in order to understand Africa one needs to understand Europe. We also look at African leaders such as Kwame Nkrumah who reminded us that the independence of his country Ghana, 


\section{Puleng Segalo}

which was the first country on the continent to gain its independence, is meaningless unless it links with the total liberation of the African continent.

6. Decolonising the university: With regard to decolonising the university, the focus has not only been on curriculum change, the school has also tried to address notions of a mindset change with regards to concepts, theories, pedagogies, and epistemologies, as has been demonstrated by the work delivered by the annual speakers. One of the critical issues the school focuses on is the need to shift from what Lewis Gordon calls 'disciplinary decadence' where one is preoccupied with the discipline without paying attention to or acknowledging the challenges faced by communities. To this end, the school also highlights the importance of trans-disciplinarity.

One of the outputs that resulted directly from the school, linked to decolonising the university, was an edited book: Decolonizing the University, Knowledge Systems and Disciplines in Africa (2016) edited by Sabelo J. Ndlovu-Gatsheni and Siphamandla Zondi, both of whom participated in the Summer School.

\section{Teaching and Learning: Building a Curriculum around Decolonial Scholarship}

ROZENA MAART: What kind of work did the presenters send for reading? How did this assist in the further conceptualisation of the project, specifically with regard to the development of the project, the pushing back of barriers, the landscaping and mapping of the project, and the extension of the concept, 'decolonial', that you first worked with when the Decolonial Summer School started?

PULENG SEGALO: We sought to invite a diverse group of scholars to facilitate and be presenters at the school. Apart from the South African presenters, several presenters came from various parts of the world, for example, Mexico, the United States of America (USA) and India. Most of the colleagues invited from the USA are all originally from other parts of the world (e.g. West Africa, Jamaica, Puerto Rico, etc.) and they brought that experience and wealth of knowledge with them. While we had a goal in terms of what we would like to achieve, we decided to be non-prescriptive in terms of what the presenters chose to present and prescribe for reading. This worked well as it 
allowed presenters the freedom to shape their allocated session, in other words what they deemed useful and relevant to the overall project. This led to various approaches of [to] the notion of what decolonial means being accommodated, and a creative licence with which to approach the seminars being offered. We were hoping for a thinking that is [was] 'outside the box' and one that zooms in on highlighting the multiple-perspectives and the usefulness thereof. A good example of this was Lewis Gordon's seminar on the importance of 'shifting the geography of reason' and creating the possibility by which to establish new forms of reason. His work focuses on ways in which we need to be critical of disciplinary canons and embrace multiple sites of knowledge production. On the other hand, previous speakers such as Oyeronke Oyewumi, Pumla Dineo Gqola and Linda Alcoff reminded us of the complexities of the notion of gender and the problematic ways in which it is often theorised.

From one year to the next, we engage with both presenters and participants on what works and what does not, to continuously reshape the space and allow it to speak to the needs of those who are in attendance. This works well as it allows and shows the importance of multiple voices and perspectives in the shaping and reshaping of the school. Due to time limitations and the set-up of the physical spaces we use, not all recommendations and suggestions could be accommodated all the time. The participants' feedback always plays a critical role in determining and deciding on the relevant speakers to invite. Following the first few Summer Schools hosted, it became clear that participants were yearning for engagements that focused on African experiences. The first few Summer Schools were helpful in laying down the theoretical foundations of what decoloniality means and what it would mean to decolonise. The School offered conceptual and theoretical tools that participants could take back to their studies and the relevant academic departments with which they are affiliated. The School also attracted participants from nongovernmental organisations and the corporate environment. It was mostly at this point that voices requesting a more practical focus became audible. While several academics and students called for praxis, to colleagues from outside academia this request seemed more urgent. This led to looking back at how the School is structured and finding ways in which we could engage practical possibilities of how to move decoloniality forward. The project grew to include additional aspects that function independently, but with the same goal. For example, The College of Human Sciences has developed a module in decoloniality, which is offered at honours level and, since it started, the uptake has been 


\section{Puleng Segalo}

high, to the point that some students are requesting that there should be a full programme in decoloniality. Secondly, the College hosts a biennial international decoloniality conference and, so far, two conferences have been held. The conference offers an opportunity for delegates to share information on their work in progress, the challenges and frustrations they experience within their various institutions, and supervision issues that postgraduate students are confronted with when they use decoloniality as an epistemological framework. These additional parts of the project have opened opportunities to take the work forward in interesting ways.

\section{The Decolonial Academic Agenda in South Africa}

MAART: How do you see yourself contributing to the overall agenda of the country?

PULENG SEGALO: From my home department, Psychology, which aims at contributing towards the emotional well-being of people, to the College that puts transformation, decolonisation and re-Africanisation at the core of its mission, to the University that aims to play a pivotal role in being a contributor towards servicing humanity, and a country that has developmental goals that aim at centring social justice through the various individual aspects it highlights, it is my belief that our decoloniality project contributes towards the realisation of the aforementioned objectives. It is also my contention that the UNISA decoloniality project contributed to fuelling the \#FeesMustFall movement, a movement that was aimed at highlighting the plight of South African students. While the focus, at least in public, seemed to have been on the unaffordability of fees, the students had also made it clear that there is a need to decolonise the curriculum, linking it to exorbitant fees they have to pay for an education that alienates them from themselves, their histories and knowledge of their people. The decoloniality project contributed towards many universities in South Africa embarking on transformation, decolonisation and re-curriculation processes. Since the project started, I have been invited to speak on decolonisation issues at several local universities, e.g., Rhodes University, Nelson Mandela University and North-West University - both the Potchefstroom and the Vaal campuses. The relevant education agenda continues to be critical for the effective functioning of the country and, through our project, we have carved pathways towards the realisation of an education 
system that speaks to and contributes to finding responses to the challenges faced by society.

\section{Decoloniality and Pedagogy}

ROZENA MAART: What are some of the pedagogical issues you entered the project with and how has this extended or exceeded what you first had in mind?

PULENG SEGALO: My entry into the decolonial project came about because of several questions I had regarding the academic project more broadly, and knowledge production within my discipline of Psychology in particular. Reflecting on the challenges faced by society due to the oppressive past many of the citizens faced, I felt we needed pedagogical tools to enable us to make sense of what our role is as creators and facilitators of knowledge. Many of our disciplines have not offered us the skills or tools to make sense of our past, our histories, and ways in which we can re-imagine and re-member our fractured existence. For a long time, there seemed to be an over-reliance on imported theories that were imposed and assumed to be universal and, as a result, applicable regardless of context. Some of the epistemological underpinnings and theoretical frameworks we draw from are not applicable to the contexts to which they end up being applied. To give an example of one of the modules I teach, community psychology; in this module we engage extensively with communities around us and, for a long time, there seemed to be a disconnect between the theories that were imposed on both students and communities theories that were drawn upon to make sense of people's lived experiences. Entering the space of decoloniality and extensively engaging with what it means to decolonise, opened avenues for me; it was as if the oxygen tank was opened and finally, I could breathe.

\section{Trends and Difficulties}

ROZENA MAART: What were/ are some of the trends you noticed among the scholars who came to the Decolonial Summer School?

PULENG SEGALO: As I indicated earlier, the School invited a diverse group of scholars whose work, it was hoped, would contribute toward assisting the participants with the conceptual and theoretical grounding of what decoloni- 


\section{Puleng Segalo}

sation is and what it means to decolonise. The scholars came from various schools of thought and with varied expertise. What I noticed was that they all brought their experiences based on their contexts and understanding of decolonisation from those spaces. They provided a wider view of how they engage the colonialism lineages and ways in which backward tracing assists in working towards decolonial possibilities. The scholars did not necessarily subscribe to the same way of understanding decoloniality and these, sometimes, diverse views allowed for robust debates, critiques, disagreements and heated engagements. Some scholars were more open to critiques from participants, while others were not.

ROZENA MAART: What are some of the unforeseen difficulties that you encountered and that you think or believe the school faced, whether you anticipated these or not?

PULENG SEGALO: The School is open to anyone interested in engaging with issues relating to decolonisation and, as a result, it attracts participants from various contexts such as academics, students, people from nongovernmental organisations and people from the private sector. Many participants come with expectations and hopes of what they will gain from the School and sometimes these are unfortunately not met. Several participants, especially those from 'non-academic' sectors, highlighted the absence of a focus on communities and indicated that this is a shortcoming that requires attention. At the same time, participants from various spheres have enriched the content that the School has to offer, as they brought their experiences with them and grappled with ways in which decoloniality is relevant for the work they do. Because the School takes place in January, at the beginning of the academic year, it sometimes coincides with the period during which the University is engaged in the collective bargaining process with labour organisations and this means the possibility of being caught in the middle of protests. This happened on a few occasions, leading to the need for immediate measures to be taken and a venue had to be sought, outside of the University campus, to host the School.

In addition to the above, we have experienced challenges linked to the actual organising of the School, where, on a number of occasions, a committee would be put in place to assist with the planning and organising of the School, but the committee would end up not functioning properly. Lastly, by its nature, 
the School 'forces' both participants and scholars who lead the discussions to engage with uncomfortable but necessary issues linked to notions of race, class, gender, to name a few, and how these are linked to colonialism. The discussions lend themselves to many people revisiting and being open about their experiences of oppression, discrimination, exclusion, and suffering. Questions such as 'Whose pain matters?' and 'Who decides what gets privileged in the space?' becomes very contested at times. It is these slippery slopes that one can never anticipate but need a cushion for people to land softly on as they journey into this decolonisation process.

\section{The Way Forward}

ROZENA MAART: What is the way forward for the Decolonial Summer School and what has been learnt in the process?

PULENG SEGALO: It is our hope that the School will continue until we have reached as many people - students, academics, and colleagues from outside academia - as possible. Additionally, we would like to see that what people have learnt at the School has been translated into actions in the various spaces they occupy, for instance in their teaching practices, and in the work that they do within communities and in private organisations, where issues of coloniality continue being a challenge. Some of the lessons we have learnt, which are mostly based on the feedback received from participants, is the importance of having facilitators who are familiar with the history of Africa in general and South Africa in particular. There has also been a call to create more space at the school for the role and need for Africanisation. The School will continue to be a space that allows people to reflect, confront and question, where they feel free to 'burp' out the traumas that so many of them carry. We have also learnt that more support and follow up might be needed, where people could go back, as it were, to the engagements that took place at the School. For us, the space and process regarding the decoloniality project is a continuous opportunity to learn, re-learn, re-shape and be humble, as we miss steps along the way. Finally, we envisage the School contributing to the overall national agenda of creating a South Africa that nurtures its people and respects the humanity of all through recognising for example, the need for good, [high] quality and relevant education that prepares and inculcates citizens that are geared towards social justice. 


\section{Conclusion}

This article offered personal reflections of my involvement and participation in the UNISA Decolonial Summer School. The dialogue structure afforded me the opportunity to offer scholarly reflection on the successes, challenges, and possibilities the School has in pushing forward the decolonial agenda. I conclude by drawing from the Ghanaian concept of Sankofa which speaks of the importance of looking back in order to move forward; to assert that this reflective article allowed for 'taking stock' of where the School comes from, how it came into being, and the way in which it could be taken forward. As South Africa and the world continue to grapple with issues of social justice that have their genesis in colonialism, the decolonisation project offers possibilities of rethinking and re-imagining a future that highlights above all, the importance of all humanity.

Acknowledgements: I would like to acknowledge Ms. Kelebamang Mokgupi for having been part of the project, as one of the main organisers, from its inception and for her support in ensuring the success and continuity of the project. I also appreciate all the participants over the years, the guest lecturers, and the College of Human Sciences executive management members. The National Institute for the Humanities and Social Sciences is also hereby acknowledged for its financial support towards the 2017 Summer School.

\section{References}

Davis, A. 1983. Race, Women and Class. New York: Vintage Books.

De Sousa Santos, B. 2016. Epistemologies of the South: Justice against Epistemicide. London: Routledge.

https://doi.org/10.4324/9781315634876

Fanon, F. [1961] 1963. The Wretched of the Earth. New York: Grove Press.

Fanon, F. 1986. Black Skin, White Masks. Markmann, C.L. (trans.). London: Pluto Press.

Freire, P. 2007. Pedagogy of the Oppressed. Continuum: New York.

Gordon, L. 2006. Disciplinary Decadence: Living Thought in Trying Times. London: Routledge

Grosfoguel, R. 2007. The Epistemic Decolonial Turn. Cultural Studies 21: 211

- 223. https://doi.org/10.1080/09502380601162514 
Lugones, M. 2010. Toward a Decolonial Feminism. Hypatia 25,4: 742 - 759. https://doi.org/10.1111/j.1527-2001.2010.01137.x

Maldonado-Torres, N. 2011. Thinking through the Decolonial Turn: Postcontinental Interventions in Theory, Philosophy, and Critique: An Introduction. Transmodernity 1,2: 1 - 15.

Manganyi, N.C. 2013. On Becoming a Psychologist in Apartheid South Africa. South African Journal of Psychology 43,1: 278 - 288.

https://doi.org/10.1177/0081246313493597

Mignolo, W. 2013. Geopolitics of Sensing and Knowing on (De)Coloniality, Border Thinking, and Epistemic Disobedience. Confero 1,1: 129 - 150.

https://doi.org/10.3384/confero.2001-4562.13v1i1129

Ndlovu, S. 2013. Coloniality of Power in Post-Colonial Africa: Myths of Decolonisation. Dakar: Codesria.

Ndlovu-Gatsheni, S.J. \& S. Zondi (eds.). 2016. Decolonizing the University, Knowledge Systems and Disciplines in Africa. North Carolina: Carolina Academic Press.

Nwoye, A. 2015. What is African Psychology the Psychology of? Theory and Psychology 14 January: 1 - 21.

https://doi.org/10.1177/0959354314565116

Nwoye, A. 2017. A Postcolonial Theory of African Psychology: A Reply to Kopano Ratele. Theory \& Psychology 23 March: 1-9.

https://doi.org/10.1177/0959354317700000

Oyewumi, O. 1997. The Invention of Women. Making an African Sense of

Western Gender Discourses. Minneapolis: University of Minnesota Press. Ratele, K. 2016. Four (African) Psychologies. Theory \& Psychology 22 December: 1 - 15 .

wa Thiong'o, N. 1986. Decolonizing the Mind. London: Heinemann.

wa Thiong'o, N. 2009. Re-membering Africa. Nairobi: East African Educational Publishers, Ltd.

Puleng Segalo Associate Professor Department of Psychology University of South Africa

Pretoria

South Africa segalpj@unisa.ac.za 